\title{
P-T history of kimberlite-hosted garnet lherzolites from South-West Greenland
}

\author{
Mark T. Hutchison, Louise Josefine Nielsen and Stefan Bernstein
}

Exploration for diamonds in West Greenland has experienced a major boost within the last decade following the establishment of world-class diamond mines within the nearby Slave Province of the Canadian Arctic. Numerous companies have active programmes of diamond exploration and increasingly larger diamonds have been discovered, notably a 2.392 carat dodecahedral stone recovered by the Canadian exploration company Hudson Resources Inc. in January 2007. The Geological Survey of Denmark and Greenland (GEUS) is currently carrying out several studies aimed at understanding the petrogenesis of diamondiferous kimberlites in Greenland and the physical and chemical properties of their associated mantle source regions (e.g. Hutchison 2005; Nielsen \& Jensen 2005).

Constraint of the mantle geotherm, i.e. the variation of temperature with depth for a particular mantle volume, is an important initial step in assessing the likelihood of such a volume to grow diamonds and hence the diamond potential of associated deep-sourced magmatic rocks occurring at surface. Cool geotherms are often present within old cratonic blocks such as West Greenland (Garde et al. 2000) and provide a good environment for the formation of diamonds (Haggerty 1986). This study aims to constrain the mantle geotherm for the southern extent of the North Atlantic Craton in Greenland by applying three-phase geothermobarometry calculations using chemical compositions of clinopyroxene, orthopyroxene and garnet from four-phase kimberlite-hosted lherzolite xenoliths.

Xenoliths have been sampled from kimberlites from two areas in South-West Greenland: Midternæs and Pyramidefjeld (Fig. 1). Kimberlites in the Pyramidefjeld area principally occur as sheeted sills hosted in the Pyramidefjeld granite complex of Palaeoproterozoic Ketilidian age. In contrast, Midternæs kimberlites occur as outcrops within a single, extensive and undulating sill hosted within pre-Ketilidian granodioritic gneiss and Ketilidian supracrustal rocks.

Pyramidefjeld kimberlites have been shown to be Mesozoic (Andrews \& Emeleus 1971), and work is currently being carried out to further constrain the ages of these and the Midternæs kimberlites and also xenoliths using modern methods. No attempt is made herein to provide a correct petrological classification of the rocks hosting the xenoliths; however, the abundance of clinopyroxene reported by Andrews \& Emeleus (1971) suggests that further work may more correctly conclude a classification as 'orangeite' after Mitchell (1995). Notwithstanding this, the term 'kimberlite' is employed throughout in order to be consistent with that adopted by previous authors. The Precambrian Pyramidefjeld granite complex and adjacent Archaean granodioritic gneisses are host to several kimberlite sheets located at various levels between 400 and 900 m elevation (Fig. 1A; Andrews \& Emeleus 1971, 1975). Kimberlites are mainly found as loose
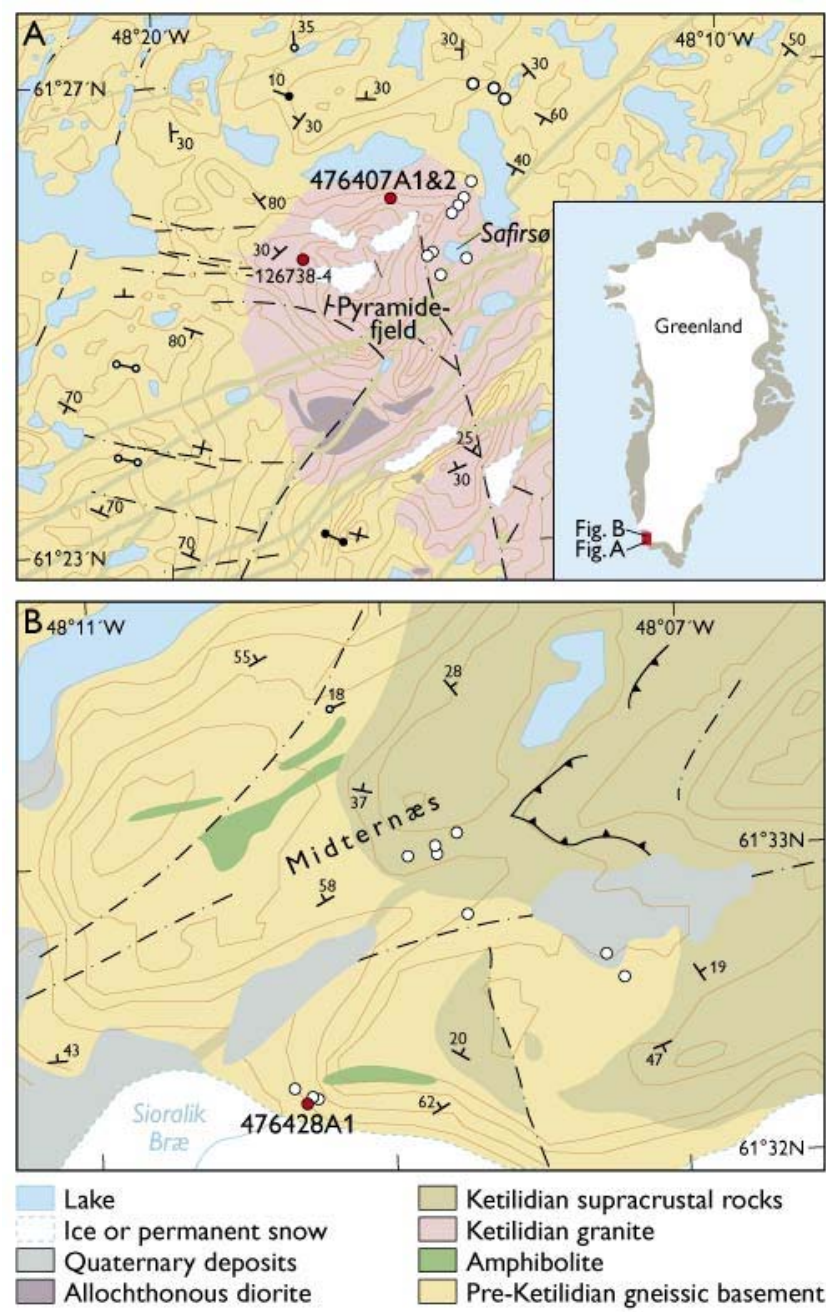

Fig. 1. Location of sample sites with reference to context in South-West Greenland (index map). Red dots indicate location of samples used for pressure and temperature calculation; white dots indicate additional samples. A: Sample localities in the Pyramidefjeld region. Geology simplified from Henriksen (1966). B: Sample localities in the Midternæs region. Geology simplified from Escher \& Jensen (1972). 


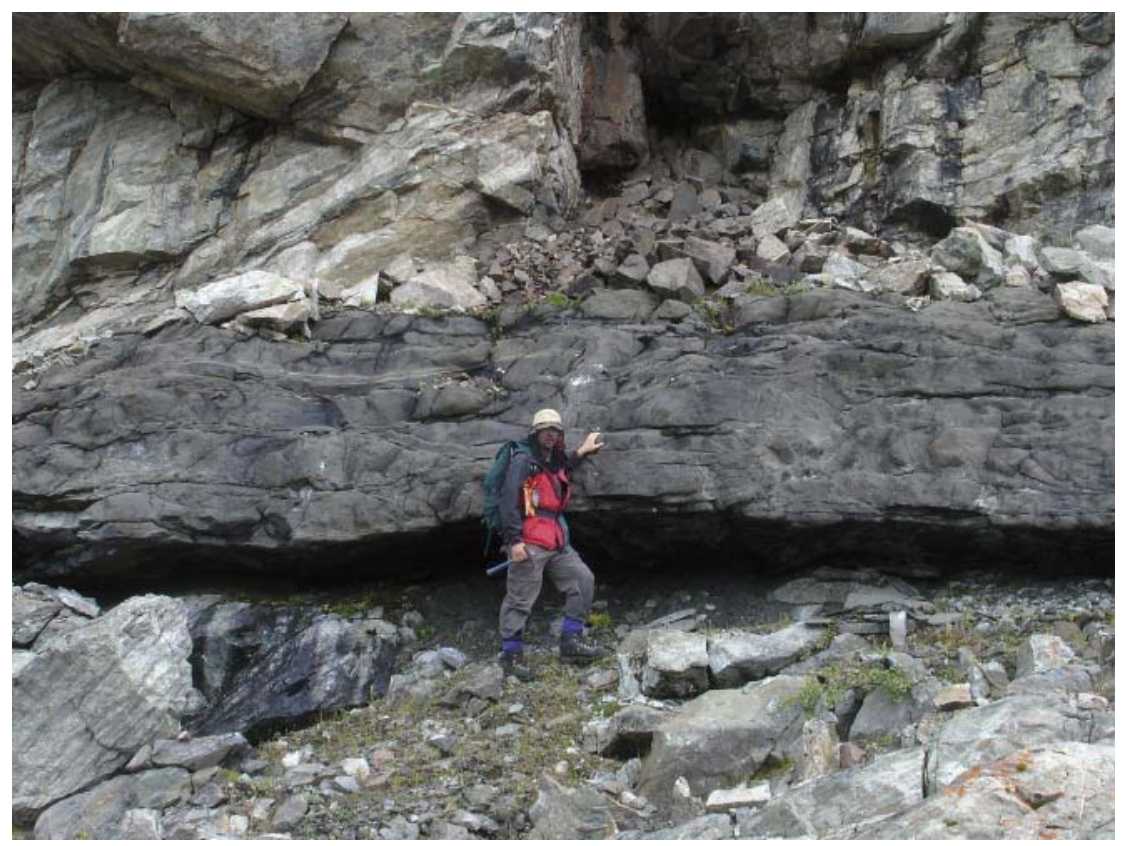

Fig. 2. Kimberlite sill of approximately $3.5 \mathrm{~m}$ thickness intruded within pre-Ketilidian gneiss and cross-cutting a vertical Gardar age (c. 1200 $\mathrm{Ma}$ ) dolerite dyke. Located at Midternæs by the glacier Sioralik Bræ (see Fig. 1B).

blocks in scree; however, these are almost always sourced locally from in situ bodies. Sheets can often be found deep within overhanging clefts, particularly in granitic walls. The kimberlite bodies are gently dipping, typically 20 degrees, and with a range of strikes. The maximum thickness of sills is approximately $2 \mathrm{~m}$ but thickness varies significantly over short distances. In many instances, the occurrence of kimberlite is seen to be controlled locally by structures in the country rocks. Field observations of the range of orientations of intrusive bodies do not appear to suggest a particular focal point which could be a likely location for an intrusive centre such as a pipe. This observation is in line with what is seen throughout West Greenland where kimberlite emplacement appears as dykes and sills (Larsen \& Rex 1992) rather than the pipes and blows which are common in other world-wide settings. The occurrence of xenoliths amongst Pyramidefjeld kimberlites is highly variable with the most xenolith-rich localities being in the vicinity of Safirsø (Fig. 1A). The majority of xenoliths are dunites with occasional wehrlites and lherzolites (Emeleus \& Andrews 1975). Of particular interest from the point of view of thermobarometry is the occurrence of garnet. This is rarely found, even in clinopyroxene-bearing samples, and the two samples chosen for thermobarometry (Fig. 1A) represent the majority of the garnet-bearing xenoliths identified within an estimated total population of 75 xenoliths collected.

The Midternæs kimberlites are hosted in Archaean gneisses and Proterozoic supracrustal rocks (Fig. 1B; Andrews \& Emeleus 1971, 1975). The style of kimberlite emplacement and occurrence of garnet-bearing xenoliths are closely similar to those of Pyramidefjeld. Contours of elevation be- tween outcrops suggest that the kimberlites form parts of a largely contiguous single body dipping at approximately 30 degrees to the west-south-west. Individual outcrops as in Pyramidefjeld indicate that the body varies in thickness and undulates in response to local structure. The south-western portion of the body which outcrops near the glacier Sioralik Bræ, is considerably thicker than elsewhere (Fig. 2) and in some places is seen to have a true thickness in excess of $4 \mathrm{~m}$. Xenoliths are less abundant on average than in Pyramidefjeld kimberlites, but a similar variety and proportion of rock types and infrequent occurrence of garnet is observed.

The kimberlites from both areas were intruded along zones of platy jointing which likely were caused by degassing of the magma and formed just prior to the kimberlite intrusion. In contrast to some kimberlites in other cratons, very few xenoliths of local, lower crustal rock types have been recognised in the kimberlites from Pyramidefjeld and Midternæs. The intrusions are therefore believed to have been of a non-explosive nature, perhaps because of host-rock rheology or due to emplacement at relatively deep crustal levels.

Here we report on calculations of equilibrium pressure and temperature using compositions of three-phase assemblages of garnet, orthopyroxene and clinopyroxene from Midternæs and Pyramidefjeld mantle xenoliths.

\section{Measurements}

Polished thin sections of garnet-bearing mantle xenoliths were prepared from fresh samples from both localities. Most xenoliths have a coarse granular texture indicative of equilibrium growth amongst clinopyroxene, olivine, orthopyroxene 
and garnet. Typically, triple junctions between mineral grains are well defined. Mineral compositions were determined by the JEOL 733 electron microprobe at the Department of Geography and Geology, University of Copenhagen. Analyses were conducted using a $15 \mathrm{kV}, 15 \mathrm{nA}$ and $5 \mu \mathrm{m}$ beam for the elements $\mathrm{Si}, \mathrm{Ti}, \mathrm{Al}, \mathrm{Cr}, \mathrm{Fe}, \mathrm{Mn}, \mathrm{Ni}, \mathrm{Mg}, \mathrm{K}$ and $\mathrm{Na}$. Standardisation was achieved against natural and synthetic standards.

\section{Geothermobarometry}

Estimates of the temperatures and pressures within the Earth are essential for the understanding of many geological processes and in particular, in the case of kimberlites, for diamond prospectivity. Geothermobarometry is based on the study of mineral assemblages in chemical and physical equilibrium. As mantle xenoliths often retain information about the physical conditions at the time of formation, they are widely used for such estimates. In this study temperature-pressure calculations are based on the two-pyroxene thermometer and the aluminium-in-orthopyroxene / garnet barometer of Brey \& Köhler (1990). Results are presented in the context of standard cratonic mantle geotherm models in Fig. 3. Pressure and temperature estimates from Pyramidefjeld range from $909^{\circ} \mathrm{C}$ and $3.29 \mathrm{GPa}$ to $975^{\circ} \mathrm{C}$ and $3.50 \mathrm{GPa}$. These pressures correspond to a depth range of $106-113 \mathrm{~km}$. Peak assemblages using cores of touching grains for samples from Pyramidefjeld fall on a smooth curve. The Midternæs sample reflects equilibrium conditions of $1087^{\circ} \mathrm{C}$ and $3.73 \mathrm{GPa}$ corresponding to $120 \mathrm{~km}$ depth and therefore deeper than the Pyramidefjeld samples. All values show a similarity with a warm mantle geotherm based on a surface heat flow of 44 $\mathrm{mW} / \mathrm{m}^{2}$ after Pollack \& Chapman (1977). However, the location of pressure and temperature points more closely follows the trends in the steady-state geotherm of McKenzie et al. (2005) although at an average temperature elevated by approximately $50^{\circ} \mathrm{C}$ (Fig. 3). Furthermore, the Midternæs sample may reflect the same type of high-T inflection evident under similar conditions from Lesotho kimberlite-hosted xenoliths (Finnerty 1989) although further data are required to confirm this inference.

\section{Discussion and conclusions}

The apparent coincidence of pressure and temperature values for xenoliths from Pyramidefjeld and Midternæs along the McKenzie et al. (2005) geotherm suggests that the thermal conditions of the mantle sampled from the two localities separated on the ground by $14 \mathrm{~km}$ are largely the same. The McKenzie et al. (2005) model takes account of lower radiogenic heating in the cratonic crust than previously accepted

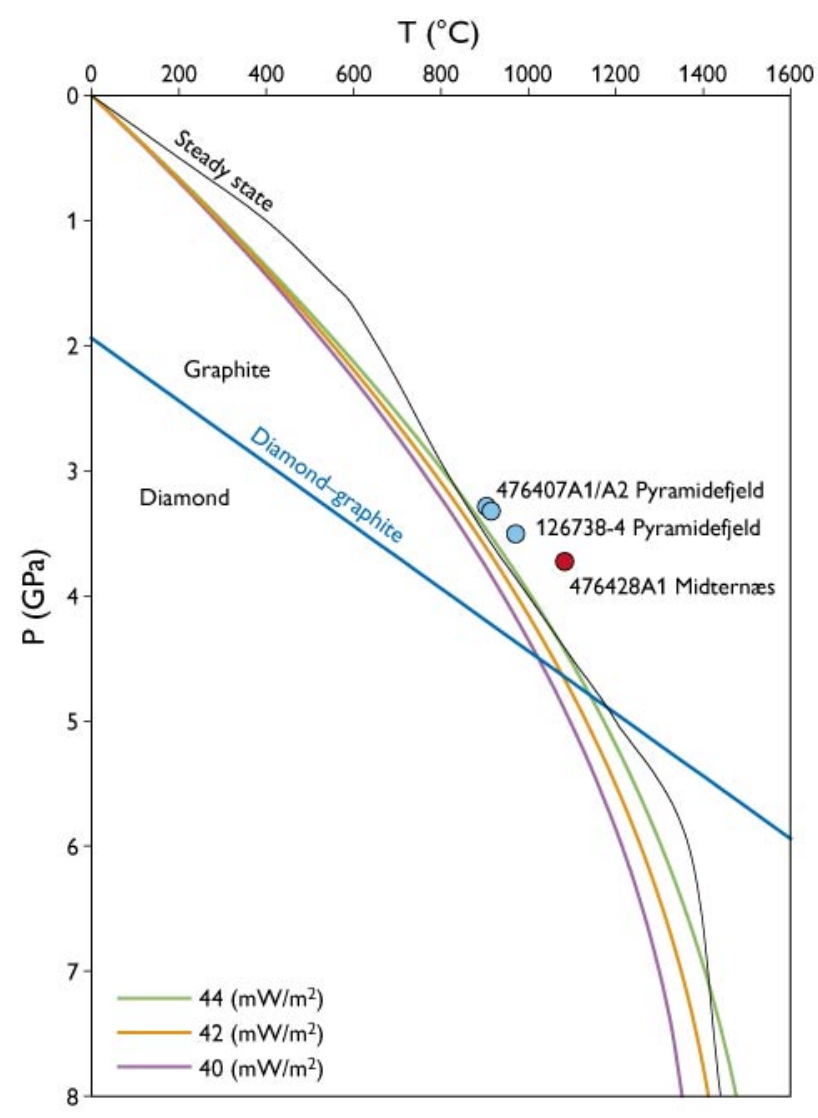

Fig. 3. Temperature-pressure diagram showing positions of equilibrium conditions for garnet lherzolite xenoliths in this study in the context of mantle geotherms. Diamond-graphite phase boundary after Kennedy \& Kennedy (1976) and steady-state mantle geotherm after McKenzie et al. (2005). Mantle geotherms from Pollack \& Chapman (1977) where figures represent surface heat flow for each model in $\mathrm{mW} / \mathrm{m}^{2}$. Calculated pressures and temperatures are for peak conditions (cores of mineral grains).

and shows good correlation with pressure and temperature estimates from kimberlite-hosted mantle xenoliths from northern Canada and central Siberia (McKenzie et al. 2005 and references therein). Results from Pyramidefjeld and Midternæs xenoliths are hence also consistent with kimberlite-hosted xenoliths from elsewhere whilst at the same time elevated temperatures observed in this study suggest that the geotherm was slightly warmer in South-West Greenland than in the northern Canada and central Siberian diamond-bearing mantle.

Additional samples are required to more closely constrain the geotherm and also to assess the ranges of depths from which xenoliths were sampled at the two locations; however, the greater depth represented so far at Midternæs may have significance. Midternæs is slightly closer to the central part of the craton, and the greater depths represented in the xenolith suite may thus reflect a thicker cratonic lithospheric root. 
Consequently the present data suggest that the Midternæs kimberlite is closer to directly sampling mantle material within the diamond stability field than Pyramidefjeld. Although xenolith suites may be formed under different conditions compared to diamonds found within the same kimberlites (Shee et al. 1982), it appears that Midternæs may have a better diamond potential than Pyramidefjeld. Midternæs kimberlites have not so far been tested for the presence of diamonds, and the apparently shallower-sourced kimberlites from Pyramidefjeld have yielded small numbers of diamonds (unpublished company reports collated in Jensen et al. 2004). Since Midternæs contains some of the thickest outcropping kimberlite evident in Greenland, the area may merit further attention by diamond prospectors.

\section{Acknowledgements}

Graham Pearson, Geoff Nowell and Nadine Wittig (University of Durham) are acknowledged for support. MTH acknowledges the European Community's 6th Framework Program for support under a Marie Curie EIF Fellowship. Disclaimer: This publication reflects the authors' views, and the European Community shall not be held liable for any use of the information contained herein.

\section{References}

Andrews, J.R. \& Emeleus, C.H. 1971: Preliminary account of kimberlite intrusions from the Frederikshåb district, South-West Greenland. Rapport Grønlands Geologiske Undersøgelse 31, 26 pp.

Andrews, J.R. \& Emeleus, C.H. 1975: Structural aspects of kimberlite dyke and sheet intrusion in South-West Greenland. Physics and Chemistry of the Earth 9, 43-50.

Brey, G.P. \& Köhler, T. 1990: Geothermobarometry in four-phase lherzolites II. New thermobarometers, and practical assessment of existing thermobarometers. Journal of Petrology 31, 1353-1378.

Emeleus, C.H. \& Andrews, J.R. 1975: Mineralogy and petrology of kimberlite dyke sheet intrusions and included peridotite xenoliths from South-West Greenland. Physics and Chemistry of the Earth 9, 179-197.
Escher, J.C. \& Jensen, S.B. 1972: Geological map of Greenland, 1:100 000, Midternæs 61 V.2 Nord. Copenhagen: Geological Survey of Greenland. Finnerty, A.A. 1989: Xenolith-derived mantle geotherms: whither the inflection? Contributions to Mineralogy and Petrology 102, 367-375.

Garde, A.A., Friend, C.R.L., Nutman, A.P. \& Marker, M. 2000: Rapid maturation and stabilisation of middle Archaean continental crust: the Akia terrane, southern West Greenland. Bulletin of the Geological Society of Denmark 47, 1-27.

Haggerty, S. 1986: Diamond genesis in a multi-constrained model. Nature 320, 34-38.

Henriksen, N. 1966: Geological map of Greenland, 1:100 000, Ivigtut 61 V.1 Syd. Copenhagen: Geological Survey of Greenland.

Hutchison, M.T. 2005: Diamondiferous kimberlites from the Garnet Lake area, West Greenland: exploration methodologies and petrochemistry. Danmarks og Grønlands Geologiske Undersøgelse Rapport 2005/68, 33-42.

Jensen, S.M., Secher, K., Rasmussen, T.M. \& Schjøth, F. 2004: Diamond exploration data from West Greenland: 2004 update and revision. Danmarks og Grønlands Geologiske Undersøgelse Rapport 2004/117, 90 pp.

Kennedy, C. \& Kennedy, G. 1976: The equilibrium boundary between graphite and diamond. Journal of Geophysical Research 81, 2467-2470

Larsen, L.M. \& Rex, D.C. 1992: A review of the 2500 Ma span of alkalineultramafic, potassic and carbonatitic magmatism in West Greenland. Lithos 28, 367-402.

McKenzie, D., Jackson, J. \& Priestley, K. 2005: Thermal structure of oceanic and continental lithosphere. Earth and Planetary Science Letters 233, 337-349.

Mitchell, R.H. 1995: Kimberlites, orangeites and related rocks, 410 pp. New York: Plenum Press.

Nielsen, T.F.D. \& Jensen, S.M. 2005: The Majuagaa calcite-kimberlite dyke, Maniitsoq, southern West Greenland. Danmarks og Grønlands Geologiske Undersøgelse Rapport 2005/43, 59 pp.

Pollack, H.N. \& Chapman, D.S. 1977: On the regional variation of heat flow, geotherms and lithospheric thickness. Tectonophysics $\mathbf{3 8}$, 279-296.

Shee, S.R., Gurney, J.J. \& Robinson, D.N. 1982: Two diamond-bearing peridotite xenoliths from the Finsch Kimberlite, South Africa. Contributions to Mineralogy and Petrology 81, 79-87.

\section{Authors' addresses}

M.T.H. \& S.B., Geological Survey of Denmark and Greenland, Øster Voldgade 10, DK-1350 Copenhagen K, Denmark. E-mail: mbutchis@lpl.arizona.edu L.J.N., Department of Geography and Geology, University of Copenhagen, Øster Voldgade 10, DK-1350 Copenhagen K, Denmark. 